\title{
Despite antibiotic treatment of travellers' diarrhoea, pathogens are found in stools from half of travellers at return ${ }^{\text {is }}$
}

\author{
Tinja Lääveri ${ }^{\mathrm{a}}$, Katri Vilkman ${ }^{\mathrm{a}}$, Sari Pakkanen ${ }^{\mathrm{b}}$, Juha Kirveskari ${ }^{\mathrm{c}, \mathrm{d}}$, Anu Kantele, ,e,f,g,* $^{\text {, }}$ \\ a Inflammation Center, Division of Infectious Diseases, University of Helsinki and Helsinki University Hospital, Helsinki, Finland, POB 348, FIN-00029 HUS, Finland \\ ${ }^{\mathrm{b}}$ Department of Bacteriology and Immunology, University of Helsinki, Helsinki, Finland, POB 21, FIN-00014 Helsinki, Finland \\ ${ }^{c}$ Helsinki University Hospital Laboratory (HUSLAB), Department of Bacteriology, Helsinki, Finland, POB 720, FIN-00029 HUS, Finland \\ d Mobidiag Ltd, Espoo, Finland, Keilaranta 16 A, FIN-02150 Espoo Finland \\ e Clinicum, University of Helsinki, Helsinki, Finland, POB 63, FI-00014 Helsinki, Finland \\ ${ }^{\mathbf{f}}$ Aava Travel Clinic, Medical Centre Aava, Helsinki, Finland, Annankatu 32, FIN-00100 Helsinki, Finland \\ ${ }^{g}$ Unit of Infectious Diseases, Department of Medicine/Solna, Karolinska Institutet, Stockholm, Sweden, SE-17176 Stockholm, Sweden
}

\section{A R T I C L E I N F O}

\section{Keywords:}

EPEC

EAEC

ETEC

Campylobacter

Diarrhoeagenic Escherichia coli

Shigella

\begin{abstract}
A B S T R A C T
Background: Among visitors to the (sub)tropics, 20-50\% contract travellers' diarrhoea (TD) and 5-30\% take antibiotics. While shortening the duration of illness, antimicrobials predispose to acquisition of multi-drug resistant bacteria. Therefore, liberal use is no longer advocated. Although antibiotics kill pathogens, no data support the view that they could prevent post-infectious sequelae. We investigated how antibiotic use for TD abroad impacts the pathogen findings at return.

Materials and methods: We revisited 456 travellers' clinical data and stool pathogens examined by qPCR for Salmonella, Yersinia, Campylobacter, Shigella, Vibrio cholerae and enteroaggregative (EAEC), enteropathogenic (EPEC), enterotoxigenic (ETEC), enterohaemorrhagic (EHEC) and enteroinvasive (EIEC) Escherichia coli.

Results: Among travellers with TD, antibiotic users had pathogen-positive samples less frequently than non-users ( $50 \%$ versus $83 \%$ ). The difference was significant for EPEC ( $23 \%$ versus $47 \%$ ) and EAEC ( $27 \%$ versus $54 \%$ ), but not ETEC (17\% versus 26\%) or the other pathogens. Shigella/EIEC was found more often among antibiotic users than non-users ( $4 \%$ versus $1 \%$ ).

Conclusion: Despite antibiotic treatment of TD, half of the users still had stool pathogens at return, reflecting either antibiotic resistance of pathogens or recolonisation/reinfection while abroad. Treatment of TD with antibiotics during travel should not be interpreted to indicate eradication of pathogens.
\end{abstract}

\section{Introduction}

Of the 80-100 million contracting travellers' diarrhoea (TD) annually, 5-30\% take antibiotics [1-11]. Antibiotic use for TD - a disease which generally remains mild or moderate and resolves spontaneously - has recently been debated, since ample studies show that antimicrobials used during travel double the risk of becoming colonised by intestinal multidrug-resistant bacteria, especially extended-spectrum beta-lactamase-producing Enterobacteriaceae (ESBL-PE) [7,8,10-12]. Despite this risk, some guidelines [13] still recommend antibiotics as an alternative even for non-severe cases. Besides shortening the duration of TD, another justification for liberal use has been the presumed potential of antibiotics, by rapidly killing pathogens, to prevent postinfectious sequelae such as irritable bowel syndrome (IBS) [13].

TD is mostly caused by bacterial pathogens (50-80\%) [13-16]. Numerous investigations suggest that although antibiotics are taken to kill pathogens, eradication rates do not correlate with cure [17-22]. Indeed, pathogens are still found, although in reduced numbers, in stool samples collected shortly after a course of antibiotics, completed while abroad [17-22]. Many studies looking at samples collected from returning travellers at home omit to specify whether antibiotics have been used during travel or not $[14,15]$; only few report separately the findings of those having taken antibiotics [23]. To obtain data on the impact of antibiotic use on post-travel pathogen findings, we revisited a

\footnotetext{
Abbreviations: AB, Antimicrobial/antibiotic; DEC, diarrhoeagenic Escherichia coli; EAEC, enteroaggregative Escherichia coli; EHEC, enterohaemorrhagic Escherichia coli; EIEC, enteroinvasive Escherichia coli; EPEC, enteropathogenic Escherichia coli; ETEC, enterotoxigenic Escherichia coli; qPCR, quantitative PCR; TD, travellers' diarrhoea

if Preliminary results of this study were presented at the 15th Conference of the International Society of Travel Medicine (CISTM) in Barcelona $14-18$ May 2017.

* Corresponding author. Inflammation Center, Division of Infectious Diseases, Helsinki University Hospital, POB 348, FIN-00029 HUS, Finland.

E-mail addresses: tinja.laaveri@hus.fi (T. Lääveri), katri.vilkman@gmail.com (K. Vilkman), sari.pakkanen@helsinki.fi (S. Pakkanen), juha.kirveskari@mobidiag.com (J. Kirveskari), anu.kantele@hus.fi (A. Kantele).
} 


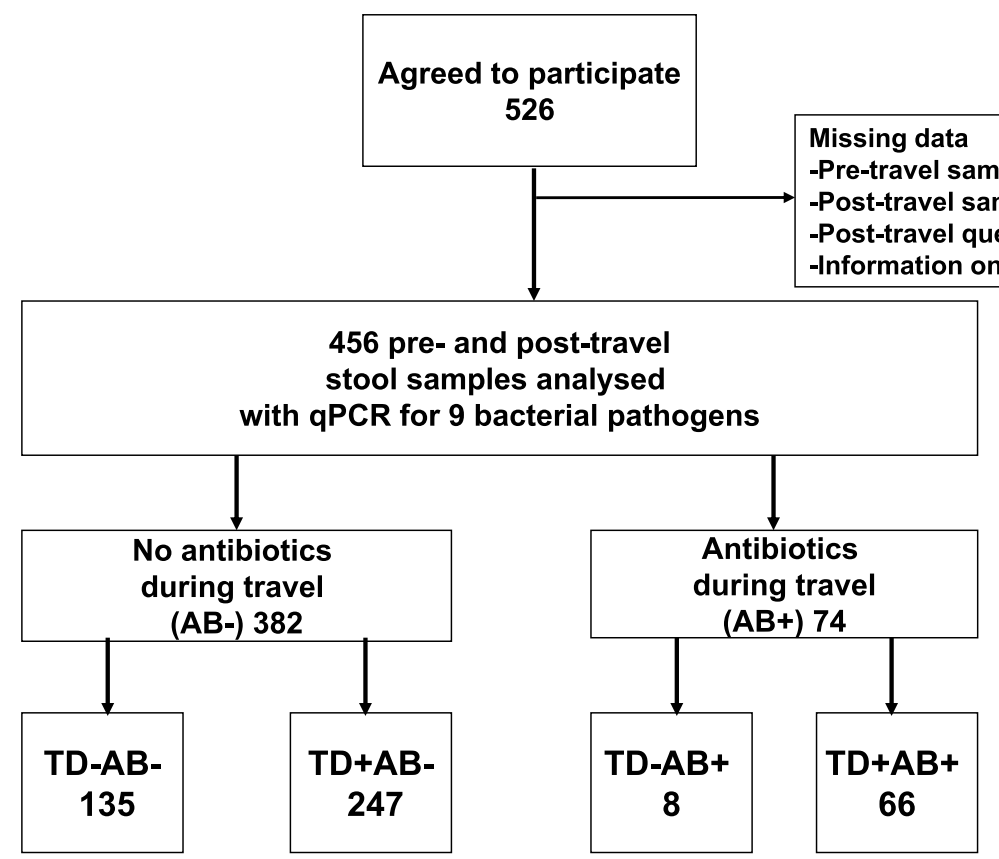

Fig. 1. Study protocol for investigating bacterial pathogen findings among Finnish travellers with respect to occurrence of TD and use of antibiotics.

data set collected on 456 Finnish travellers and compared individual results among those having taken versus not taken antimicrobials.

\section{Methods}

\subsection{Study design and volunteers}

The study was designed to assess how antibiotic use during travel impacts the bacterial pathogen findings in stool samples taken at return. We revisited our data on 526 Finnish travellers recruited 2009-2010 $[16,24]$, selecting 456 who all had provided information on their use of antibiotics and provided both pre- and post-travel stool samples (Fig. 1).

The Ethics Committee of the Helsinki University Hospital approved the study protocol. All volunteers had given written informed consent. We have earlier reported stool pathogen findings among travellers visiting various regions of the world [24] and among those without antibiotic use [16,25] as well as the findings of resistant Enterobacteriacae [7,26,27], and travel-related health problems [28].

\subsection{Definitions and categorisation of travel destinations}

TD was defined according to the World Health Organisation (WHO) criteria for diarrhoea as loose/liquid stools three times per day or more frequently than usual for the individual, as previously described [16]. Severe TD was defined as six or more loose/liquid stools per day, TD accompanied by fever or overt blood in stools or TD requiring hospitalisation. Based on the presence or absence of symptoms at the time of the post-travel sampling, those with TD were further categorised into resolved TD and ongoing TD. Travel destinations were grouped into nine regions as modified from the United Nations classification, in line with our previous study [24] (Table 1).

Study participants were divided into four groups by the presence or absence of TD and antibiotic use (AB) during travel: 1) no TD and no antibiotic use (TD-AB-), 2) no TD but antibiotics taken during travel $(\mathrm{TD}-\mathrm{AB}+), 3)$ TD during travel but no antibiotic use (TD $+\mathrm{AB}-)$, and 4) $\mathrm{TD}$ and antibiotic use during travel $(\mathrm{TD}+\mathrm{AB}+)$. Since doxycycline as an antimalarial is taken throughout a journey, and is thus not expected to cause a sudden temporary impact on gut microbiota while abroad, we chose to include doxycycline users in the $\mathrm{AB}$ - group if no other antibiotics had been taken. The same approach has been used in studies assessing the impact of antibiotic use on risk of acquiring ESBL-PE $[7,8]$.

\subsection{Collection and laboratory analysis of stool samples}

Collection and handling of the stool samples and the multiplex qPCR method have been described previously [29]. In short, after returning home, the travellers provided a post-travel sample from the first (or second) stools. The faecal samples were collected as swabs in Copan M40 Transystem tubes (Copan Diagnostics, Brescia, Italy) and mailed to the laboratory. Once arrived (within one to three days after sampling), total nucleid acids were extracted using the standard semi-automated protocol of easyMAG (bioMérieux, Marcy-l'Etoile, France). The analyses were carried out with a multiplex QPCR method that covers the following pathogens: diarrhoeagenic $E$. coli including enteroaggregative (EAEC), enteropathogenic (EPEC), enterotoxigenic (ETEC), enterohaemorrhagic (EHEC) and enteroinvasive (EIEC) E. coli or Shigella as well as Salmonella, Yersinia, Vibrio cholerae and Campylobacter coli/ jejuni.

\subsection{Statistical analysis}

Statistical analyses were carried out with SPSS 22 (IBM Corp, Armonk, NY).

The chi-square test or Fisher's exact test were used to compare categorical variables when applicable. Binomial regression model was used to obtain profile likelihood confidence intervals for the proportions of the various pathogens in geographical regions or, in cases where computation did not converge, asymptotic Wald confidence intervals were used. The possible differences in the effect of antibiotics on pathogen findings (those associated with TD in our previous study: any pathogen, EPEC, EAEC, ETEC or Campylobacter [15]) was compared in the five most popular regions with binomial logistic regression analysis (interaction between antibiotic and region). Statistical significance was determined as either $95 \%$ confidence intervals not overlapping, or ranging only either above or below 1 . 
Table 1

Characteristics of 456 Finnish travellers with or without TD (TD + and TD-) and using or not using antibiotics (AB + and AB-). ${ }^{\text {a }}$

\begin{tabular}{|c|c|c|c|c|c|}
\hline & \multicolumn{4}{|l|}{$\mathrm{AB}+/-\mathrm{TD}+/-$} & \multirow{2}{*}{$\begin{array}{c}\text { Total } \\
\text { N (\%) }\end{array}$} \\
\hline & AB-TD-N (\%) & $\mathrm{AB}-\mathrm{TD}+\mathrm{N}(\%)$ & $\mathrm{AB}+\mathrm{TD}-\mathrm{N}(\%)$ & $\mathrm{AB}+\mathrm{TD}+\mathrm{N}(\%)$ & \\
\hline Ongoing TD symptoms & 0 & $115(47)$ & 0 & $28(42)$ & $143(46)$ \\
\hline Age (years) median & 46 (IQR 30-60) & 33 (IQR 27-50) & 27.5 (IQR 23-60.25) & 32.5 (IQR 28-56.75) & 36 (IQR 27-54.25) \\
\hline Male & $54(40)$ & $95(38)$ & $4(50)$ & $21(32)$ & $174(38)$ \\
\hline Female & $81(60)$ & $152(62)$ & $4(50)$ & $45(68)$ & $282(62)$ \\
\hline Duration of travel (days), median & 15 (IQR 10-18) & 17 (IQR 14-28.25) & 34 (IQR 12.75-75) & 26 (IQR 16-39.5) & 16 (IQR 13-27) \\
\hline South Asia & $12(9)$ & $40(16)$ & $2(25)$ & $15(23)$ & $69(15)$ \\
\hline Southeast Asia & $23(17)$ & $68(28)$ & $1(13)$ & $15(23)$ & $107(23)$ \\
\hline South and Central America and the Caribbean & $16(12)$ & $20(8)$ & $0(0)$ & $4(6)$ & $40(9)$ \\
\hline Europe, Australia, North America & $13(10)$ & $3(1)$ & $1(13)$ & $0(0)$ & $17(4)$ \\
\hline East Asia & $3(2)$ & $2(1)$ & $0(0)$ & $2(3)$ & $7(2)$ \\
\hline Northern Africa and Middle East & $7(5)$ & $4(2)$ & $0(0)$ & $1(2)$ & $12(3)$ \\
\hline Southern Africa & $11(8)$ & $10(4)$ & $1(13)$ & $2(3)$ & $24(5)$ \\
\hline Western and Middle Africa & 25 (19) & $43(17)$ & $3(38)$ & $13(20)$ & $84(18)$ \\
\hline Eastern Africa & 25 (19) & $57(23)$ & $0(0)$ & $14(21)$ & $96(21)$ \\
\hline Total (\% of all travellers) & $135(30)$ & 247 (54) & $8(2)$ & 66 (15) & 456 (100) \\
\hline
\end{tabular}

a Doxycycline as continuing antimalarial included in $\mathrm{AB}-$ if no other antibiotic was used.

\section{Results}

\subsection{Traveller characteristics and use of antibiotics}

The background data for the 456 travellers are provided in Table 1. In total, 74 travellers (16\%) reported antibiotic use during journey; $89 \%(66 / 74)$ of them had taken antibiotics for TD. Of these regimens, $50(76 \%)$ were fluoroquinolones and eleven (17\%) macrolides. The probability of taking antibiotics for TD was found similar across the various geographical regions $(\mathrm{p}=0.737)$.

Of travellers with TD, $21 \%(66 / 313)$ took antibiotics, whereas among the asymptomatic, antibiotic use was reported by $6 \%(8 / 143)$. Symptoms were still ongoing at return among $47 \%(115 / 247)$ of those in group $\mathrm{TD}+\mathrm{AB}-$ and $42 \%(28 / 66)$ in group $\mathrm{TD}+\mathrm{AB}+(\mathrm{p}=0.549)$.

\subsection{Bacterial pathogen findings among travellers having used antibiotics}

Bacterial pathogens were found in a total of $49 \%$ of the post-travel stool samples from antibiotic users (Table 2$) ; 19 \%(n=14)$ had two or more types of pathogens $(14 / 36 ; 39 \%$ of those with a pathogen finding). EAEC (20; 27\%), EPEC (17; 23\%) and ETEC (11; 15\%) were the most frequent findings, followed by Campylobacter (3; 4\%), Shigella/ EIEC (3; 4\%), EHEC (2; 3\%) and Salmonella (2; 3\%). No Vibrio cholerae or Yersinia were detected.

In the whole group of 456 travellers, antibiotic use was associated with fewer findings of any pathogen, multiple pathogens, EPEC or EAEC, but more frequent cases of Shigella/EIEC. Doxycycline as an antimalarial had no impact on pathogen findings.

\subsection{Comparisons of findings among travellers with TD and with and without use of antibiotics}

Among those with TD, the proportion of pathogen-positive stool samples was found lower among antibiotic users than non-users (33/66; $50 \%$ versus $205 / 247 ; 83 \%$ ) (Table 2.). The difference was statistically significant also for EPEC (15/66; 23\% versus $117 / 247 ; 47 \%)$ and EAEC (18/66; 27\% versus 133/247; 54\%), but not ETEC $(11 / 66 ; 17 \%$ versus 64/247; 26\%), Campylobacter (3/66; 5\% versus $25 / 247 ; 10 \%$ ) or other pathogens.

Of the 50 travellers reporting use of fluoroquinolones, Campylobacter was detected in the stools from three (6\%); the proportion was practically the same $(7 \%)$ among those having not taken antibiotics. Among those having used macrolides $(\mathrm{n}=11)$, no Campylobacter was found.

\subsection{Differences in impact of antibiotics on pathogen findings across geographical regions}

There was no significant interaction between antibiotic use and region with regard to any of the pathogens (Table 3.).

\section{Discussion}

Despite antimicrobial medications earlier being the mainstay of TD treatment, few are the studies that report post-travel findings related to taking them. Our results show antibiotic use to be associated with a lower proportion of pathogen-positive stool samples - $\mathrm{AB}$ users $50 \%$ versus non-users $83 \%$ - yet even among the users bacterial pathogens were seen in half of the samples after return.

\subsection{High rates of pathogens after antibiotic use}

Pathogen findings despite antibiotic treatment may reflect not only acquisition during continuing exposure afterwards but also the pathogens not being affected by the drugs taken, due to either initial resistance or one developed over the course. In fact, new resistant pathogens can even be favoured during antibiotic use because of selection pressure and decreasing colonisation resistance. Indeed, we have recently showed that fluoroquinolone users are prone to contract ESBL-PE strains resistant to fluoroquinolone antibiotics [27].

\subsection{Antibiotic use reduced findings with EAEC and EPEC but not with ETEC}

As expected, among those with TD, the proportion of pathogenpositive stool samples proved lower for antibiotic users than non-users ( $50 \%$ vs. $83 \%$ ). This finding contrasts the results of Gascon et al. [23], who explored returning travellers with TD: prior antibiotic use did not influence the proportion of pathogens in this group. The study does not report findings with individual pathogens [23]. In our study, antibiotic use reduced the findings with EAEC ( $23 \%$ vs. $47 \%)$ and EPEC (27\% vs. $54 \%$ ), but not other individual pathogens (Table 2.). The results accord with those reported by Schultz et al. [1] who found EAEC and diffusely adherent $E$. coli but not ETEC in reduced proportions, if returning travellers had taken antibiotics while abroad. The resistance rates for ETEC, and EAEC have increased over the years [30,31]; research into the resistance for EPEC is scarce. We believe that the smaller impact of antibiotic use on ETEC rates rather reflects this pathogens' relatively fast disappearance from the stools. In our previous report on travellers not having used antimicrobials [16] ETEC was identified at lower rates among travellers with resolved $(22 / 132 ; 17 \%)$ than ongoing TD 


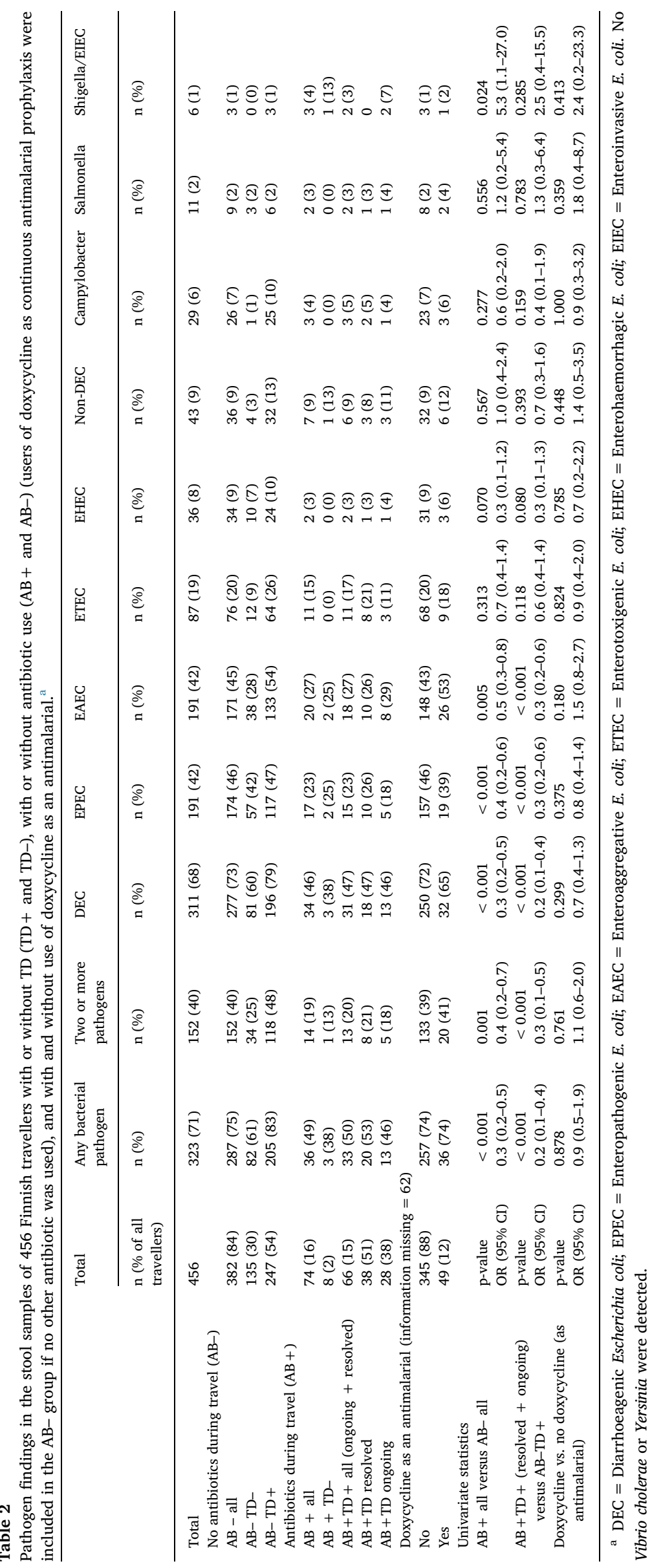


Table 3

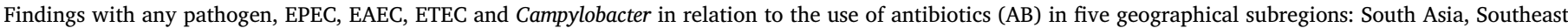
Asia, West and Central Africa, East Africa, and South and Central America, and the Caribbean.

\begin{tabular}{|c|c|c|c|c|c|c|c|c|c|c|c|}
\hline & \multirow{2}{*}{$\frac{\text { All }}{\mathrm{n}(\%)}$} & \multicolumn{2}{|c|}{ Any pathogen } & \multicolumn{2}{|c|}{ EPEC } & \multicolumn{2}{|c|}{ EAEC } & \multicolumn{2}{|c|}{ ETEC } & \multicolumn{2}{|c|}{ Campylobacter } \\
\hline & & $\mathrm{n}$ & $\%(95 \% \mathrm{CI})$ & $\mathrm{n}$ & $\%(95 \% \mathrm{CI})$ & $\mathrm{n}$ & $\%(95 \% \mathrm{CI})$ & $\mathrm{n}$ & $\%(95 \% \mathrm{CI})$ & $\mathrm{N}$ & $\%(95 \% \mathrm{CI})$ \\
\hline \multicolumn{12}{|c|}{ South Asia } \\
\hline Total & 69 (15) & 54 & $78(69-88)^{*}$ & 37 & $54(42-66)$ & 39 & 57 (45-69) & 15 & $22(12-32)$ & 12 & 17 (8-27) \\
\hline $\mathrm{AB}-$ & $52(75)$ & 45 & $87(77-96)^{*}$ & 29 & 56 (42-69) & 32 & $62(48-74)$ & 12 & $23(13-36)$ & 10 & $19(10-31)$ \\
\hline \multicolumn{11}{|c|}{ Southeast Asia } & $12(2-32)$ \\
\hline Total & $108(26)$ & 74 & $69(60-77)^{*}$ & 44 & $41(31-50)$ & 34 & $31(23-41)$ & 20 & $19(11-26)$ & 13 & $12(6-18)$ \\
\hline $\mathrm{AB}-$ & $91(84)$ & 65 & $71(62-80)$ & 42 & $46(36-56)$ & 30 & $33(24-43)$ & 18 & $20(13-29)$ & 11 & $12(6-20)$ \\
\hline $\mathrm{AB}+$ & $16(16)$ & 8 & $50(27-73)$ & 2 & $13(2-34)$ & 3 & $19(5-42)$ & 1 & $6(0-25)$ & 1 & $6(0-25)$ \\
\hline \multicolumn{12}{|c|}{ West and Central Africa } \\
\hline Total & 85 (19) & 60 & $71(61-80)^{*}$ & 36 & $42(32-53)$ & 39 & $46(35-57)$ & 14 & $16(8-25)$ & 1 & $1(0-3)^{*}$ \\
\hline $\mathrm{AB}-$ & $68(80)$ & 51 & $75(64-84)$ & 31 & $46(34-57)$ & 34 & $50(38-62)$ & 11 & $16(9-26)$ & 0 & 0 \\
\hline $\begin{array}{l}\mathrm{AB}+ \\
\text { East Af }\end{array}$ & $16(20)$ & 8 & $50(27-73)$ & 4 & $25(9-49)$ & 5 & $31(13-56)$ & 3 & $19(5-42)$ & 0 & 0 \\
\hline Total & $96(21)$ & 80 & $83(76-91)^{*}$ & 45 & $47(37-57)$ & 50 & $52(42-62)$ & 32 & $33(24-43)$ & 5 & $5(1-10)$ \\
\hline $\mathrm{AB}-$ & $82(85)$ & 71 & $87(79-94) *$ & 44 & $54(43-64)$ & 45 & $55(44-65)$ & 28 & $34(25-45)$ & 5 & $6(2-13)$ \\
\hline $\mathrm{AB}+$ & $14(15)$ & 9 & $64(39-89)^{*}$ & 1 & $7(0-28)$ & 5 & $36(15-62)$ & 4 & $29(10-54)$ & 0 & 0 \\
\hline \multicolumn{12}{|c|}{ South and Central America and Caribbean } \\
\hline Total & 40 & 31 & $78(65-90) *$ & 17 & $43(26-59)$ & 15 & $38(22-53)$ & 4 & $10(0-20)$ & 0 & 0 \\
\hline $\mathrm{AB}-$ & $36(90)$ & 30 & $83(69-93)$ & 20 & $56(39-72)^{*}$ & 15 & $42(27-58)$ & 4 & $11(4-24)$ & 0 & 0 \\
\hline $\mathrm{AB}+$ & $4(10)$ & 1 & $25(0-67)^{*}$ & 3 & $75(33-100)^{*}$ & 0 & 0 & 0 & 0 & 0 & 0 \\
\hline \multicolumn{12}{|c|}{ Statistical analysis on difference between regions (interaction $A B^{*}$ region) } \\
\hline P-value & in effect of $A B$ & 0.6 & & 0.290 & & 1.0 & & 0.85 & & 1.0 & \\
\hline
\end{tabular}

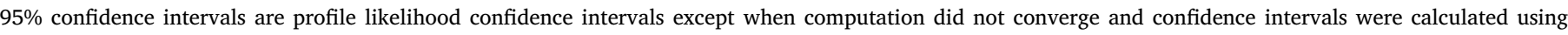
asymptotic Wald formula (marked with *).

symptoms (42/115; 37\%; OR:2.9:95\% CI:1.6-5.2); the same did not appear to apply to EAEC.

Interestingly, the impact of antibiotic treatment on pathogen detection rates did not differ between the various geographical regions (Table 3), suggesting that differences in resistance do not account for the findings after antibiotic use, at least not entirely.

\subsection{Shigella/EIEC more common after antibiotic use}

It is noteworthy that during travel Shigella/EIEC was seen more frequently among antibiotic users than non-users. Even though the proportion of travellers carrying Shigella/EIEC remained small, this finding could reflect antibiotics disrupting colonisation resistance, thus facilitating colonisation and infection with pathogenic bacteria. Indeed, antimicrobial treatment has been found to be associated with increased risk of contracting Salmonella $[32,33]$ and any bacteria resistant to the antibiotic administered [27]; we are not aware of any similar reports concerning Shigella/EIEC.

\subsection{Campylobacter not found after macrolide use}

The finding that Campylobacter was detected among travellers having used fluoroquinolones but not among those who had taken macrolides accords with the commonness of fluoroquinolone resistance among Campylobacter strains particularly in South and Southeast Asia [34], where the majority of our cases with Campylobacter had visited [24]; strains from these geographical regions are still mostly sensitive to macrolides [34]. In line with our results, prior treatment with FQ but not macrolide antibiotics has been shown to be connected with Campylobacter findings [35]. However, Campylobacter eradication rates have not been associated with clinical cure [18,21]. Interestingly, among our travellers, the clinical picture of TD was similar for macrolide $(4 / 9$; $44 \%$ severe TD) and fluoroquinolone (21/48; 44\% severe TD) users.

\subsection{Doxycycline as antimalarial has no impact on pathogen findings}

When taken as an antimalarial during the journey, no effect was seen of doxycycline on pathogen findings. This was expected, since doxycycline is no longer considered a valid drug for intestinal pathogens $[13,30]$ nor in prevention of TD [13,36]. Moreover, in one study [36], doxycycline as an antimalarial did not influence the pathogen findings among travellers with TD; those remaining asymptomatic were not included in the analyses.

\subsection{Considerations of antibiotic use for TD}

Liberal use of antibiotics for TD has been justified by the disruption to travel plans caused by TD [13]. In addition, theoretic preventive effect on post-TD sequelae such as IBS has been suggested [13]. However, the relationship between common TD pathogens and IBS is not clear: in the study by Nair et al. only LT-ETEC and Providencia spp. were associated with post-travel functional abdominal symptoms; none of the pathogens analysed related to IBS [37]; they did not report possible antibiotic use. Moreover, in two large prospective traveller studies [5,9], and in one randomised trial [38], antimicrobials had no effect on the risk of post-travel IBS. Contrariwise, some investigations have shown that taking them for TD or infectious diarrhoea rather increases the risk of IBS [39,40]. Pathogens found in stools after antibiotic treatment, as seen in our research, may partly explain why antibiotics used to treat TD have not reduced the risk of IBS.

The proportion of travellers with symptoms still ongoing at return was similar between $\mathrm{TD}+\mathrm{AB}-(47 \%)$ and $\mathrm{TD}+\mathrm{AB}+(42 \%)$ groups. The lack of difference may be explained by $32 \%$ of the volunteers (data not shown) having taken, instead of antibiotics, loperamide, a drug effective for TD [41] which does not predispose to acquisition of multidrugresistant bacteria [26]. Actually, in our recent review, we found no studies comparing the efficacy of loperamide to current antibiotics taken singly for TD, but it is evident that both are efficacious in treating the disease [41].

\subsection{Implications for further research}

When assessing the role of various aetiological agents in TD, a number of investigations have overlooked the possible use of antibiotics 
earlier during the journey $[14,15]$, while some others have excluded from their analyses participants who had taken antibiotics three to seven days prior to stool sampling [17,19,21,22,42]. This interval appears too short, since intestinal microbiota have been shown to be affected by antimicrobials for up to twelve months [43]. If stools are analysed shortly after antibiotic treatment from samples collected while abroad [17-22,44], the results fail to represent the 'final' pathogen findings on travellers' return to better hygienic conditions at home. Our data show that the specimens of those having used antimicrobials should be examined separately, but not omitted from studies analysing the prevalence of various pathogens.

\subsection{Limitations}

The principal limitation of our study was not having available the exact start or end dates of antibiotic treatment, which made it impossible to assess the duration of the effect of antibiotics on pathogen findings and the time the travellers were exposed to new pathogens during/after the course; we had only recorded the presence/absence of symptoms at return. Changes in the intestinal microbiota have, however, been described to persist for even a year [43]. Molecular diagnostic methods have been criticized for oversensitivity in detecting pathogens $[45,46]$, yet also studies applying culture-based methods have detected bacterial pathogens in up to $33 \%$ of stools after use of antibiotics [19,21,22]. Moreover, it is unlikely that free nucleic acids could resist active DNAses in the intestinal environment and qPCR methods would thus measure non-viable bacteria [47,48]. Since diarrhoeagenic E. coli were not cultured, we have no data on the susceptibility profiles.

\section{Conclusion}

Bacterial pathogens were found in stools from half of travellers using antibiotics for diarrhoea. It appears that either the pathogens have initially been resistant to the drug taken or the individuals have contracted other, potentially resistant bacteria during or soon after the intake abroad, while still under exposure. Treatment of TD with antibiotics while abroad should not be interpreted to indicate pathogen eradication.

\section{Authors' contributions}

Study concept and design JK, AK; acquisition of data TL, KV, SHP, $\mathrm{JK}, \mathrm{AK}$; analysis and interpretation of results TL, KV, SHP, JK, AK; drafting of manuscript TL, AK; statistical analysis TL; final approval of version published TL, KV, SHP, JK, AK.

\section{Potential conflicts of interest}

TL, KV, SHP, and JK declare no conflicts of interest. AK has received honorary for lectures (Pfizer, MSD, Valneva, Immuron) and an investigator-initiated grant (Pfizer), and has on two occasions consulted an advisory board (Valneva), none of these relevant to the current manuscript.

\section{Funding}

This work was supported by a Finnish government subsidy for health science research (grant numbers: TYH2012141, TYH 2013218 and TYH 2014216), the SSAC Foundation (grant number SLS-504141), and the Paulo Foundation. The funding sources had no involvement in study design, collection, analysis and interpretation of data, devising manuscript, and decision to submit the article for publication.

\section{Acknowledgements}

We express our gratitude to the late Dr Jukka Riutta for recruiting the patients. We also thank the nurses at the Travel Clinic of Aava Medical Centre for help in recruiting the volunteers, the personnel of Helsinki University Hospital Laboratory for processing the stool specimens and Jukka Ollgren for expert advice on statistical analyses.

\section{References}

[1] Schultsz C, van den Ende J, Cobelens F, Vervoort T, van Gompel A, Wetsteyn JC, et al. Diarrheagenic Escherichia coli and acute and persistent diarrhea in returned travelers. J Clin Microbiol 2000;38:3550-4.

[2] Hill DR. Occurrence and self-treatment of diarrhea in a large cohort of Americans traveling to developing countries. Am J Trop Med Hyg 2000;62:585-9.

[3] Pitzurra R, Steffen R, Tschopp A, Mutsch M. Diarrhoea in a large prospective cohort of European travellers to resource-limited destinations. BMC Infect Dis 2010;10. 231-2334-10-231

[4] Belderok SM, van den Hoek A, Kint JA. Schim van der Loeff MF, Sonder GJ. Incidence, risk factors and treatment of diarrhoea among Dutch travellers: reasons not to routinely prescribe antibiotics. BMC Infect Dis 2011;11. 295-2334-11-295.

[5] Pitzurra R, Fried M, Rogler G, Rammert C, Tschopp A, Hatz C, et al. Irritable bowel syndrome among a cohort of European travelers to resource-limited destinations. J Trav Med 2011;18:250-6.

[6] Soonawala D, Vlot JA, Visser LG. Inconvenience due to travelers' diarrhea: a prospective follow-up study. BMC Infect Dis 2011;11. 322-2334-11-322.

[7] Kantele A, Lääveri T, Mero S, Vilkman K, Pakkanen SH, Ollgren J, Antikainen J, Kirveskari J, et al. Antimicrobials increase travelers' risk of colonization by extended-spectrum betalactamase-producing Enterobacteriaceae. Clin Infect Dis 2015;60:837-46.

[8] Ruppe E, Armand-Lefevre L, Estellat C, Consigny PH, El Mniai A, Boussadia Y, et al High rate of acquisition but short duration of carriage of multidrug-resistant Enterobacteriaceae after travel to the tropics. Clin Infect Dis 2015;61:593-600.

[9] Lalani T, Maguire JD, Grant EM, Fraser J, Ganesan A, Johnson MD, et al. Epidemiology and self-treatment of travelers' diarrhea in a large, prospective cohort of department of defense beneficiaries. J Trav Med 2015;22:152-60.

[10] Reuland EA, Sonder GJ, Stolte I, Al Naiemi N, Koek A, Linde GB, et al. Travel to Asia and traveller's diarrhoea with antibiotic treatment are independent risk factors for acquiring ciprofloxacin-resistant and extended spectrum beta-lactamase-producing Enterobacteriaceae-a prospective cohort study. Clin Microbiol Infect 2016;22:731. e1-731.e7.

[11] Arcilla MS, van Hattem JM, Haverkate MR, Bootsma MC, van Genderen PJ, Goorhuis A, et al. Import and spread of extended-spectrum beta-lactamase-producing Enterobacteriaceae by international travellers (COMBAT study): a prospective, multicentre cohort study. Lancet Infect Dis 2017;17:78-85.

[12] Ruppé E, Andremont A, Armand-Lefevre L. Digestive tract colonization by multidrug-resistant Enterobacteriaceae in travellers: an update. Trav Med Infect Dis 2018;21:28-35.

[13] Riddle MS, Connor BA, Beeching NJ, DuPont HL, Hamer DH, Kozarsky P, et al. Guidelines for the prevention and treatment of travelers' diarrhea: a graded expert panel report. J Trav Med 2017;24:S57-74.

[14] Paschke C, Apelt N, Fleischmann E, Perona P, Walentiny C, Loscher T, et al Controlled study on enteropathogens in travellers returning from the tropics with and without diarrhoea. Clin Microbiol Infect 2011;17:1194-200.

[15] Zboromyrska Y, Hurtado JC, Salvador P, Alvarez-Martinez MJ, Valls ME, Mas J, et al. Aetiology of traveller's diarrhoea: evaluation of a multiplex PCR tool to detect different enteropathogens. Clin Microbiol Infect 2014;20:0753-9.

[16] Lääveri T, Antikainen J, Pakkanen SH, Kirveskari J, Kantele A. Prospective study of pathogens in asymptomatic travellers and those with diarrhoea: aetiological agents revisited. Clin Microbiol Infect 2016;22:535-41.

[17] Ericsson CD, DuPont HL, Mathewson JJ, Johnson PC, de la Cabada FJ, Bitsura JA Test-of-cure stool cultures for traveler's diarrhea. J Clin Microbiol 1988:26:1047-9.

[18] Kuschner RA, Trofa AF, Thomas RJ, Hoge CW, Pitarangsi C, Amato S, et al. Use of azithromycin for the treatment of Campylobacter enteritis in travelers to Thailand, an area where ciprofloxacin resistance is prevalent. Clin Infect Dis 1995;21:536-41.

[19] DuPont HL, Jiang ZD, Ericsson CD, Adachi JA, Mathewson JJ, DuPont MW, et al. Rifaximin versus ciprofloxacin for the treatment of traveler's diarrhea: a randomized, double-blind clinical trial. Clin Infect Dis 2001;33:1807-15.

[20] Steffen R, Sack DA, Riopel L, Jiang ZD, Sturchler M, Ericsson CD, Lowe B, et al. Therapy of travelers' diarrhea with rifaximin on various continents. Am J Gastroenterol 2003;98:1073-8.

[21] Tribble DR, Sanders JW, Pang LW, Mason C, Pitarangsi C, Baqar S, et al. Traveler's diarrhea in Thailand: randomized, double-blind trial comparing single-dose and 3 day azithromycin-based regimens with a 3-day levofloxacin regimen. Clin Infect Dis 2007;44:338-46.

[22] DuPont HL, Petersen A, Zhao J, Mundt A, Jiang ZD, Miller S, et al. Targeting of rifamycin SV to the colon for treatment of travelers' diarrhea: a randomized, doubleblind, placebo-controlled phase 3 study. J Trav Med 2014;21:369-76.

[23] Gascon J, Vila J, Valls ME, Ruiz L, Vidal J, Corachan M, et al. Etiology of traveller's diarrhea in Spanish travellers to developing countries. Eur J Epidemiol 1993;9:217-23.

[24] Lääveri T, Vilkman K, Pakkanen SH, Kirveskari J, Kantele A. A prospective study of travellers' diarrhoea - analysis of pathogen findings by destination in various (sub) 
tropical regions. Clin Microbiol Infect 2017. http://dx.doi.org/10.1016/j.cmi.2017. 10.034 .

[25] Lääveri T, Pakkanen SH, Kirveskari J, Kantele A. Travellers' diarrhoea: impact of TD definition and control group design on study results. Trav Med Infect Dis 2018.

[26] Kantele A, Mero S, Kirveskari J, Lääveri T. Increased risk for ESBL-producing bacteria from Co-administration of loperamide and antimicrobial drugs for travelers' Diarrhea(1). Emerg Infect Dis 2016;22:117-20.

[27] Kantele A, Mero S, Kirveskari J, Lääveri T. Fluoroquinolone antibiotic users select fluoroquinolone-resistant ESBL-producing Enterobacteriaceae (ESBL-PE) - data of a prospective traveller study. Trav Med Infect Dis 2017;16:23-30.

[28] Vilkman K, Pakkanen SH, Lääveri T, Siikamäki H, Kantele A. Travelers' health problems and behavior: prospective study with post-travel follow-up. BMC Infect Dis 2016;16. 328-016-1682-0.

[29] Antikainen J, Kantele A, Pakkanen SH, Lääveri T, Riutta J, Vaara M, Kirveskari J, et al. A quantitative polymerase chain reaction assay for rapid detection of 9 pathogens directly from stools of travelers with diarrhea. Clin Gastroenterol Hepatol 2013;11:1300-7. e3.

[30] Ouyang-Latimer J, Jafri S, VanTassel A, Jiang ZD, Gurleen K, Rodriguez S, et al. In vitro antimicrobial susceptibility of bacterial enteropathogens isolated from international travelers to Mexico, Guatemala, and India from 2006 to 2008. Antimicrob Agents Chemother 2011;55:874-8.

[31] Hebbelstrup Jensen B, Olsen KE, Struve C, Krogfelt KA, Petersen AM. Epidemiology and clinical manifestations of enteroaggregative Escherichia coli. Clin Microbiol Rev 2014;27:614-30.

[32] Gradel KO, Dethlefsen C, Ejlertsen T, Schonheyder HC, Nielsen H. Increased prescription rate of antibiotics prior to non-typhoid Salmonella infections: a one-year nested case-control study. Scand J Infect Dis 2008;40:635-41.

[33] Koningstein M, Simonsen J, Helms M, Molbak K. The interaction between prior antimicrobial drug exposure and resistance in human Salmonella infections. J Antimicrob Chemother 2010;65:1819-25.

[34] Post A, Martiny D, van Waterschoot N, Hallin M, Maniewski U, Bottieau E, et al. Antibiotic susceptibility profiles among Campylobacter isolates obtained from international travelers between 2007 and 2014. Eur J Clin Microbiol Infect Dis 2017;36:2101-7.

[35] Koningstein M, Simonsen J, Helms M, Hald T, Molbak K. Antimicrobial use: a risk factor or a protective factor for acquiring campylobacteriosis? Clin Infect Dis 2011;53:644-50.

[36] Arthur JD, Echeverria P, Shanks GD, Karwacki J, Bodhidatta L, Brown JE, et al. A comparative study of gastrointestinal infections in United States soldiers receiving doxycycline or mefloquine for malaria prophylaxis. Am J Trop Med Hyg 1990;43:608-13.

[37] Nair P, Okhuysen PC, Jiang ZD, Carlin LG, Belkind-Gerson J, Flores J, et al. Persistent abdominal symptoms in US adults after short-term stay in Mexico. J Trav Med 2014;21:153-8.

[38] Okhuysen PC, Jiang ZD, Carlin L, Forbes C, DuPont HL. Post-diarrhea chronic intestinal symptoms and irritable bowel syndrome in North American travelers to Mexico. Am J Gastroenterol 2004;99:1774-8.

[39] Stermer E, Lubezky A, Potasman I, Paster E, Lavy A. Is traveler's diarrhea a significant risk factor for the development of irritable bowel syndrome? A prospective study. Clin Infect Dis 2006;43:898-901.

[40] Törnblom H, Holmvall P, Svenungsson B, Lindberg G. Gastrointestinal symptoms after infectious diarrhea: a five-year follow-up in a Swedish cohort of adults. Clin Gastroenterol Hepatol 2007;5:461-4.

[41] Lääveri T, Sterne J, Rombo L, Kantele A. Systematic review of loperamide: No proof of antibiotics being superior to loperamide in treatment of mild/moderate travellers' diarrhoea. Trav Med Infect Dis 2016;14:299-312.

[42] Jennings MC, Tilley DH, Ballard SB, Villanueva M, Costa FM, Lopez M, et al. CaseCase analysis using 7 Years of travelers' diarrhea surveillance data: preventive and travel medicine applications in Cusco, Peru. Am J Trop Med Hyg 2017;96:1097-106.

[43] Rashid MU, Zaura E, Buijs MJ, Keijser BJ, Crielaard W, Nord CE, et al. Determining the long-term effect of antibiotic administration on the human normal intestinal microbiota using culture and pyrosequencing methods. Clin Infect Dis 2015;2(60 Suppl):S77-84.

[44] Pandey P, Bodhidatta L, Lewis M, Murphy H, Shlim DR, Cave W, et al. Travelers' diarrhea in Nepal: an update on the pathogens and antibiotic resistance. J Trav Med 2011;18:102-8

[45] Vila J. New molecular diagnostic tools in traveller's diarrhea. J Trav Med 2017;24:S23-8.

[46] Zautner AE, Gross U, Emele MF, Hagen RM, Frickmann H. More pathogenicity or just more Pathogens?-On the interpretation problem of multiple pathogen detections with diagnostic multiplex assays. Front Microbiol 2017;8:1210.

[47] Netherwood T, Martin-Orue SM, O'Donnell AG, Gockling S, Graham J, Mathers JC, Gilbert HJ, et al. Assessing the survival of transgenic plant DNA in the human gastrointestinal tract. Nat Biotechnol 2004;22:204-9.

[48] Klijn N, Weerkamp AH, de Vos WM. Genetic marking of Lactococcus lactis shows its survival in the human gastrointestinal tract. Appl Environ Microbiol $1995 ; 61: 2771-4$. 